\title{
Protective Effect of Natural Honey, Urtica diocia and Their Mixture against Oxidative Stress Caused by Chronic Ethanol Consumption.
}

\author{
G.M.F Edrees", F.G.EL-Said and E.T.Salem. \\ Zoology Department, Faculty of Science, Mansoura University.
}

\begin{abstract}
Background: There is increasing implicating oxidative stress in the pathogenesis of chronic pancreatitis. The aim of this study is to investigate affect alcohol addiction and role of some protecting agent.

Material and methods: Forty eight rats (Rattus norvigicus) were divided into 8 groups. Honey (2.5 g $/ \mathrm{kg} \mathrm{b.w})$, Urtica dioica $(250 \mathrm{mg} / \mathrm{kg})$ and Alcohol orally administered at dose $(20 \%$ exceeds by $2.5 \%$ weekly).

Results: Ethanol feeding results in increasing serum glucose, total lipids, cholesterol, Low Density Lipoprotein (LDL), triglycerides, urea, liver Glucose-6-Phosphatase (G6Pase), pancreas and liver Malondialdehyde (MDA), Protein Carbonyl (PC). While a decrease were noted in serum insulin, High Density Lipoprotein (HDL), total Protein, $\mathrm{Na}, \mathrm{K}, \mathrm{Ca}, \mathrm{Mg}, \mathrm{Cu}$, liver glycogen, pancreas and liver Glucose-6-Phosphate Dehydrogenase (G6PD), GlutathioneS-Transferase (GST), Reduced Glutathione (GSH), Catalase (CAT), Superoxide Dismutase (SOD).

Conclusion: Administration of honey, urtica or both with alcohol prevent to great extent the lesions caused by only chronic alcohol administration. Consequently, honey and urtica administration are useful to minimize the hazardous effects resulting from ethanol abuse.
\end{abstract}

Key Words: Alcohol- Antioxidant- Honey- Urtica- Oxidative stress.

\section{Introduction}

It is well known that, chronic ethanol administration results in oxidative stress.

Generally, the conditions affecting cardiovascular, gastro-intestinal and the central nervous systems follow the severity of more chronic heavy alcohol use related to more significant morbidity (Meera et al., 2001).

The physiological functionality of foods has received much attention, due to the increasing interest in human health. Besides carbohydrates which are the major constituents (70-80\%), honey contains, in low amounts, various substances such as organic acids, proteins, amino acids, vitamins, enzymes, minerals and different other molecules [pigments, flavonoids, antibacterial factors, etc.] (White, 1979).

Urtica dioica herbs are used against liver insufficiency (Yesilada et al., 1993) and are used to treat stomachache in
Turkish folk medicine (Yesilada et al., 2001)

The aim of the present work is to evaluate the role of either honey, Urtica or both on the oxidative stress caused by ethanol abuse.

\section{Material And Methods}

Male Albino Rats (Rattus norvigicus) (48 rats) weighing about 100-120 g were used in these experiments.

Animals were divided into 8 groups:

1- Rats served as control

2- Rats treated with honey $(2.5 \mathrm{~g} / \mathrm{kg} \mathrm{b} . \mathrm{w}$, orally)

3- Rats treated with Urtica dioica (250 $\mathrm{mg} / \mathrm{kg}$, orally)

4- Rats treated with honey and Urtica dioica 


\section{G.M.F Edrees et al}

5- Rats treated with alcohol (20\% exceeds by $2.5 \%$ weekly, orally)

6- Rats treated with alcohol and honey

7- Rats treated with alcohol and Urtica dioica

8- Rats treated with alcohol, honey and Urtica dioica

Experimental period extended to 8 weeks after that animal were sacrificed. Serum, part of pancreas \& liver were collected for the following estimation.

Serum glucose (Trinder, 1969), insulin (Yallow and Berson, 1959), total lipid (Frings et al, 1972), total cholesterol (Young, 2001), HDL $\mathrm{C}_{\mathrm{C}}$ (Grove (1979), $\mathrm{LDL}_{\mathrm{C}}$, triglycerides (Fossati and Prencipe, 1982), urea (Palton and Crouch 1977) and total protein (Henry 1964), Na, K, Ca (ion selective electrode method using ISE AVL 988-3), Mg (Bohoun, 1962), Cu (Abe et al., 1989), liver glycogen content (Nicholas et al., 1956), liver G6Pase (Rossetti et al., 1993), as well as pancreas \& liver G6PD (Chan et al., 1965), MDA (Ohkawa et al. 1982), PC (Smith et al., 1991), GST (Habig et al., 1974), GSH (Prins and Loose, 1969), CAT (Bock et al., 1980) and SOD (Niskikimi et al., 1972).

Statistical analysis was done using SPSS.

\section{Results}

As regarding serum glucose and glucose-6-phosphatase, rats treated with alcohol alone or all other treatments showed highly significant increase $(p<0.001)$ in comparison with control rat [except rats treated with alcohol, honey\& Urtica they recorded non significant change in liver G6Pase] (table 1). Meanwhile, positive control rats treated with honey and Urtica \& honey showed significant decrease $(\mathrm{p}<0.05 \& \mathrm{p}<0.001)$ in liver G6Pase respectively. On the other hand, positive control group showed significant increase in serum insulin, liver glycogen, pancreas \& liver G6PD. While, a dramatically drop was recorded in these parameters in alcohol group or alcohol group treated with honey, Urtica or both when compared with control group.

As regarding serum total lipids, cholesterol, LDL, triglycerides and urea, rats treated with alcohol alone or other treatments, showed highly significant increase $(\mathrm{p}<0.001)$ in comparison with control rat [except rats treated with alcohol, honey\& Urtica, they recorded non significant change in total lipids, cholesterol and triglycerides] (table 2). On the other hand, positive control group treated with honey and Urtica \& honey showed significant increase in serum HDL and total protein. While, in these parameters reduced in alcohol group or alcohol group treated with honey, Urtica when compared with control group.

Table (3) represent pancreas \& liver MDA and PC, It is clear that rats treated with alcohol alone or with other treatments showed highly significant increase $(p<0.001)$ in comparison with control rat (except rats treated with alcohol, honey\& Urtica that recorded non significant change in liver PC). Meanwhile, positive control rats treated with honey and Urtica \& honey showed significant decrease in this parameter. On the other hand, positive control group treated with honey and Urtica $\&$ honey showed significant increase in pancreas \& liver GST, GSH, CAT and SOD. While, a dramatically drop was recorded in these parameters in alcohol group or alcohol group treated with Urtica or honey when compared with control group.

As regarding serum $\mathrm{Na}, \mathrm{K}, \mathrm{Ca}, \mathrm{Mg}$ and $\mathrm{Cu}$, It seems that rats treated only with alcohol or other treatments showed significant decrease $(\mathrm{p}<0.001)$ in comparison with control rat [except rats treated with alcohol, honey\& Urtica that recorded non significant change in $\mathrm{Na}$ and $\mathrm{Cu}$ ] (table 4). On the other hand, positive control group showed significant increase in $\mathrm{K}, \mathrm{Ca}, \mathrm{Mg}$ and $\mathrm{Cu}$ when compared with control group. 
Table (1) Some physiological parameters affecting carbohydrate in control and treated rats.

\begin{tabular}{|c|c|c|c|c|c|c|c|c|}
\hline Parameters & Control & Urtica & Honey & $\begin{array}{l}\text { Urtica } \\
\text { \&Honey }\end{array}$ & Alcohol & $\begin{array}{l}\text { Alcohol } \\
\text { \& Urtica } \\
\end{array}$ & $\begin{array}{l}\text { Alcohol } \\
\text { \&Honey }\end{array}$ & $\begin{array}{c}\text { Alcohol,Urtica } \\
\text { \&Honey }\end{array}$ \\
\hline $\begin{array}{l}\text { Glucose } \\
\bar{x} \pm \mathrm{SE} \\
\mathrm{mg} / \mathrm{dL} \\
\end{array}$ & $92.05 \pm 2.6$ & $86.7 \pm 2.4$ & $81.7 \pm 2.6$ & $76.6 \pm 1.9$ & $276.7 \pm 6^{* * *}$ & $193.2 \pm 5^{* * *}$ & $157.1 \pm 3.2^{* * *}$ & $126.6 \pm 3.8^{* * * *}$ \\
\hline $\begin{array}{c}\text { Insulin } \\
\bar{x} \pm \mathrm{SE} \\
\mu \mathrm{lU} / \mathrm{mL} \\
\end{array}$ & $0.99 \pm 0.01$ & $1.11 \pm 0.04^{* *}$ & $1.34 \pm 0.01^{\text {**** }}$ & $1.45 \pm 0.02^{* * * *}$ & $0.31 \pm 0.02^{* * *}$ & $0.55 \pm 0.03^{* * *}$ & $0.75 \pm 0.02^{* * *}$ & $0.86 \pm 0.02^{*}$ \\
\hline \begin{tabular}{|c||} 
Liver \\
Glycogen \\
$\overline{\mathrm{X}} \pm \mathrm{SE}$ \\
$\mathrm{mg} / 100 \mathrm{~g}$ of tissue
\end{tabular} & $18.5 \pm 0.2$ & $20.7 \pm 0.5^{* *}$ & $23.3 \pm 0.3^{* * * *}$ & $25.5 \pm 0.4^{* * * *}$ & $6.6 \pm 0.2^{* * *}$ & $10.7 \pm 0.3^{* * *}$ & $13.6 \pm 0.24^{* * *}$ & $16.2 \pm 0.34^{* * *}$ \\
\hline $\begin{array}{c}\text { Liver } \\
\text { G6Pase } \\
\overline{\mathrm{X}} \pm \mathrm{SE} \\
\mu \mathrm{mol} \mathrm{P}_{\mathrm{i}} / \mathrm{min} / \mathrm{g} \\
\text { wet tissue } \\
\end{array}$ & $0.39 \pm 0.01$ & $0.38 \pm 0.01$ & $0.28 \pm 0.01^{*}$ & $0.16 \pm 0.006^{* * *}$ & $1.2 \pm 0.05^{* * *}$ & $0.73 \pm 0.03^{* * *}$ & $0.54 \pm 0.02^{* * * *}$ & $0.47 \pm 0.005$ \\
\hline $\begin{array}{c}\text { Pancreas } \\
\text { G6PD } \\
\bar{x} \pm S E \\
\text { Unit/g wet tissue } \\
\end{array}$ & $32.9 \pm 0.5$ & $38.1 \pm 0.5^{* *}$ & $46.5 \pm 0.7^{* * * *}$ & $58.7 \pm 1.7^{* * *}$ & $8.1 \pm 0.5^{* * *}$ & $12.8 \pm 0.7^{* * *}$ & $18.8 \pm 0.8^{* * *}$ & $26.2 \pm 0.9^{* * * *}$ \\
\hline $\begin{array}{c}\text { Liver } \\
\text { G6PD } \\
\bar{x} \pm \mathrm{SE} \\
\text { Unit/g wet tissue } \\
\end{array}$ & $31.6 \pm 0.5$ & $37.5 \pm 0.5^{* *}$ & $46.2 \pm 1.1^{* * *}$ & $59.1 \pm 2.1^{* * *}$ & $8.07 \pm 0.5^{* * *}$ & $14.3 \pm 0.8^{* * *}$ & $19.7 \pm 0.8^{* * *}$ & $25.8 \pm 1.1^{* *}$ \\
\hline
\end{tabular}

$*=$ significant at $\mathrm{P}<0.05$. $* *=$ highly significant at $\mathrm{P}<0.01$. $* * *=$ very highly significant at $\mathrm{P}<0.001$. Significant relative to Control. 


\section{G.M.F Edrees et al}

Table (2) Serum lipid profile and kidney function related parameter in control and treated rats.

\begin{tabular}{|c|c|c|c|c|c|c|c|c|}
\hline Parameters & Control & Urtica & Honey & Ur\&Ho & Alcohol & $\mathrm{Al} \& \mathrm{Ur}$ & $\mathrm{Al} \& \mathrm{Ho}$ & Al,Ur\&Ho \\
\hline $\begin{array}{c}\text { Total Lipids } \\
\bar{x} \pm \mathrm{SE} \\
\mathrm{mg} / \mathrm{dL} \\
\end{array}$ & $363.6 \pm 5$ & $356.7 \pm 5$ & $343.3 \pm 4.3$ & $335 \pm 4.6^{*}$ & $476 \pm 7.4^{* * * *}$ & $434.4 \pm 5.6^{* * *}$ & $406 \pm 6.5^{* * *}$ & $384.4 \pm 3.4$ \\
\hline $\begin{array}{c}\text { Cholesterol } \\
\overline{\mathrm{x}} \pm \mathrm{SE} \\
\mathrm{mg} / \mathrm{dL}\end{array}$ & $90.4 \pm 1.4$ & $86.7 \pm 1.5$ & $83.1 \pm 1.4^{*}$ & $80.6 \pm 1.6^{* *}$ & $132 \pm 1.7^{* * *}$ & $112.6 \pm 1.7^{* * *}$ & $103.8 \pm 1.6^{* * * *}$ & $96.4 \pm 1.4$ \\
\hline $\begin{array}{l}\mathrm{HDL} \\
\overline{\mathrm{x}} \pm \mathrm{SE} \\
\mathrm{mg} / \mathrm{dL}\end{array}$ & $38.1 \pm 0.5$ & $38.7 \pm 0.6$ & $41.3 \pm 0.7^{*}$ & $44.5 \pm 0.7^{* * * *}$ & $24.2 \pm 0.5^{* * *}$ & $29.5 \pm 0.7^{* * *}$ & $33.4 \pm 0.9^{* *}$ & $36.2 \pm 0.8$ \\
\hline $\begin{array}{c}\mathrm{LDL} \\
\overline{\mathrm{x}} \pm \mathrm{SE} \\
\mathrm{mg} / \mathrm{dL} \\
\end{array}$ & $32.5 \pm 0.6$ & $28.8 \pm 0.7^{*}$ & $23.3 \pm 0.6^{* * *}$ & $18 \pm 0.4^{* * *}$ & $79.4 \pm 1.2^{* * *}$ & $58.7 \pm 0.9^{* * *}$ & $47.8 \pm 0.7^{* * *}$ & $39.1 \pm 0.7^{* * *}$ \\
\hline $\begin{array}{c}\text { Triglycerides } \\
\bar{x} \pm \mathrm{SE} \\
\mathrm{mg} / \mathrm{dL} \\
\end{array}$ & $99.1 \pm 1.5$ & $96.1 \pm 1.4$ & $92.5 \pm 1.3$ & $90 \pm 1.3^{* *}$ & $141.2 \pm 2.5^{* * * *}$ & $121.4 \pm 1.9^{* * *}$ & $112 \pm 1.6^{* * *}$ & $105.2 \pm 1.5$ \\
\hline $\begin{array}{c}\text { Total Protein } \\
\bar{x} \pm \mathrm{SE} \\
\mathrm{g} / \mathrm{dL} \\
\end{array}$ & $7.1 \pm 0.1$ & $7.3 \pm 0.08$ & $7.8 \pm 0.13^{* *}$ & $8.3 \pm 0.2^{* * *}$ & $3.2 \pm 0.05^{* * *}$ & $6.3 \pm 0.07^{* * *}$ & $6.6 \pm 0.06^{*}$ & $6.8 \pm 0.08$ \\
\hline $\begin{array}{l}\text { Urea } \\
\bar{x} \pm \mathrm{SE} \\
\mathrm{mg} / \mathrm{dL}\end{array}$ & $37.2 \pm 0.6$ & $36.4 \pm 0.5$ & $33.3 \pm 0.4^{*}$ & $30.1 \pm 0.4^{* * *}$ & $70.3 \pm 1.3^{* * *}$ & $49.5 \pm 0.8^{* * *}$ & $44.7 \pm 0.6^{* * * *}$ & $40.5 \pm 0.6^{*}$ \\
\hline
\end{tabular}

$*$ = significant at $\mathrm{P}<0.05$. ${ }^{* *}=$ highly significant at $\mathrm{P}<0.01$. ${ }^{* * *}=$ very highly significant at $\mathrm{P}<0.001$. Significant relative to Control. 
Table (3) Lipid peroxidation index, non enzymatic and enzymatic antioxidant in control and treated rats.

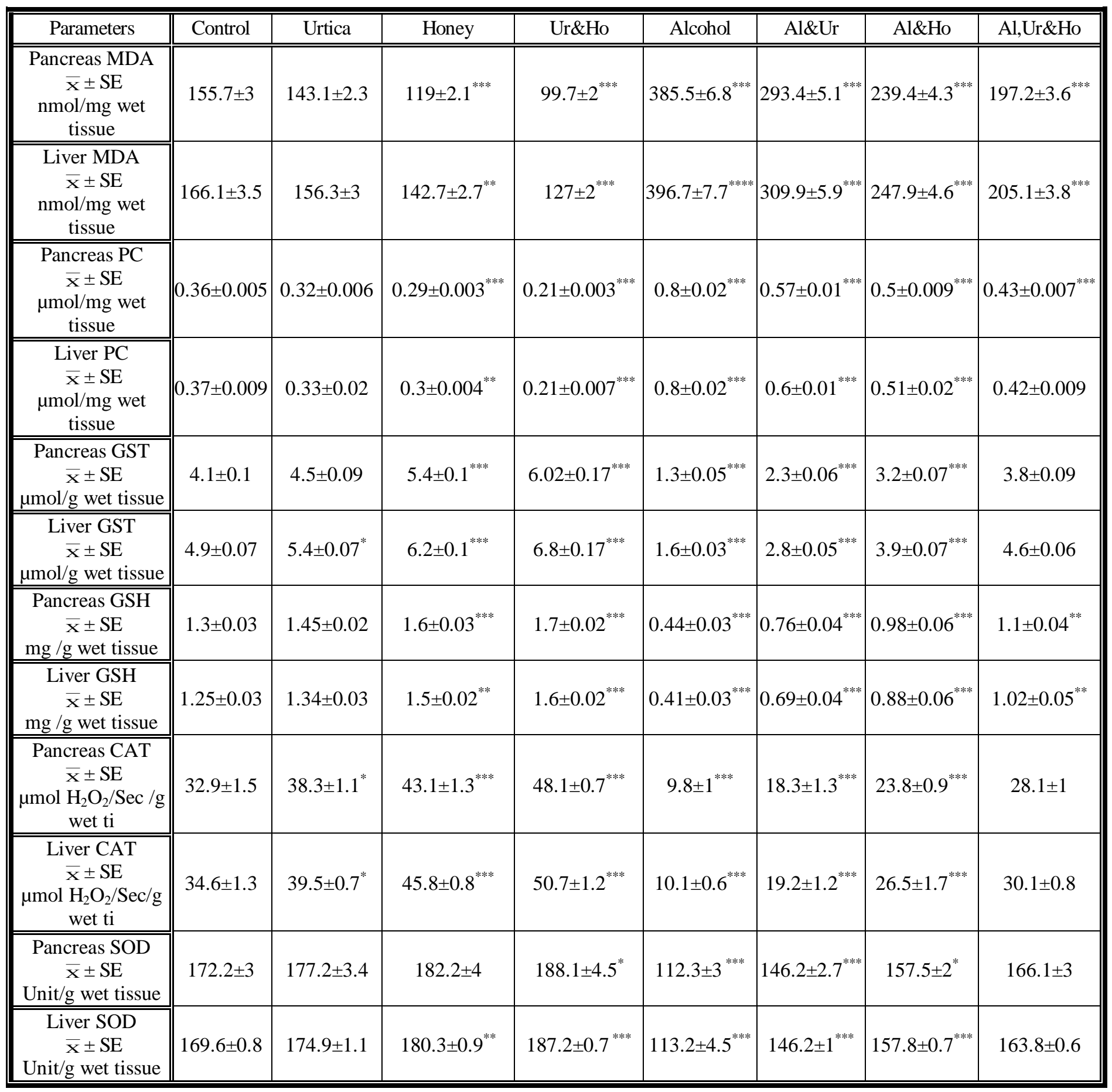

$*=$ significant at $\mathrm{P}<0.05 . * *=$ highly significant at $\mathrm{P}<0.01 . * * *=$ very highly significant at $\mathrm{P}<0.001$. Significant relative to Control. 


\section{G.M.F Edrees et al}

Table (4) Serum mineral concentration in control and treated rats.

\begin{tabular}{|c|c|c|c|c|c|c|c|c|}
\hline Parameters & Control & Urtica & Honey & Ur\&Ho & Alcohol & Al\&Ur & Al\&Ho & Al,Ur\&Ho \\
\hline \begin{tabular}{l}
\multicolumn{1}{c}{$\mathrm{Na}$} \\
$\overline{\mathrm{x}} \pm \mathrm{SE}$ \\
$\mathrm{mg} / \mathrm{dL}$
\end{tabular} & $144.4 \pm 3.4$ & $147.9 \pm 3$ & $151.4 \pm 3$ & $154.9 \pm 4$ & $96.5 \pm 2.6^{* * * *}$ & $118.6 \pm 2^{* * *}$ & $128.1 \pm 1.9^{* *}$ & $136.8 \pm 2.7$ \\
\hline \begin{tabular}{l}
\multicolumn{1}{c}{$\mathrm{Ka}$} \\
$\bar{x} \pm \mathrm{SE}$ \\
$\mathrm{mg} / \mathrm{dL}$ \\
\end{tabular} & $5.3 \pm 0.1$ & $5.8 \pm 0.1$ & $6.9 \pm 0.16^{* * *}$ & $7.6 \pm 0.2^{* * *}$ & $2.2 \pm 0.02^{* * * *}$ & $3.2 \pm 0.07^{* * *}$ & $4.3 \pm 0.08^{* * *}$ & $4.8 \pm 0.08^{*}$ \\
\hline \begin{tabular}{c}
\multicolumn{1}{c}{$\mathrm{Ca}$} \\
$\overline{\mathrm{x}} \pm \mathrm{SE}$ \\
$\mathrm{mg} / \mathrm{dL}$
\end{tabular} & $7 \pm 0.07$ & $7.5 \pm 0.07^{* *}$ & $8.4 \pm 0.04^{\text {**** }}$ & $9 \pm 0.08^{* * *}$ & $3 \pm 0.05^{* * *}$ & $5 \pm 0.06^{* * *}$ & $5.7 \pm 0.06^{* * * *}$ & $6 \pm 0.05^{* * *}$ \\
\hline \begin{tabular}{l}
\multicolumn{1}{c}{$\mathrm{Mg}$} \\
$\overline{\mathrm{x}} \pm \mathrm{SE}$ \\
$\mathrm{mg} / \mathrm{dL}$ \\
\end{tabular} & $1.9 \pm 0.04$ & $2.1 \pm 0.03^{* *}$ & $2.3 \pm 0.03^{* * *}$ & $2.5 \pm 0.04^{* * *}$ & $0.7 \pm 0.02^{* * * *}$ & $1.2 \pm 0.01^{* * *}$ & $1.5 \pm 0.02^{* * *}$ & $1.7 \pm 0.02^{* * *}$ \\
\hline \begin{tabular}{l}
\multicolumn{1}{c}{$\mathrm{Cu}$} \\
$\bar{x} \pm \mathrm{SE}$ \\
$\mathrm{mg} / \mathrm{dL}$
\end{tabular} & $1.09 \pm 0.03$ & $1.25 \underset{*}{ \pm 0.02}$ & $1.5 \pm 0.035^{* * *}$ & $1.6 \pm 0.04^{* * *}$ & $0.3 \pm 0.01^{* * *}$ & $0.65 \pm 0.01^{* * *}$ & $0.85 \pm 0.02^{* * * *}$ & $0.99 \pm 0.03$ \\
\hline
\end{tabular}

$*=$ significant at $\mathrm{P}<0.05$. $* *=$ highly significant at $\mathrm{P}<0.01$. $* * *=$ very highly significant at $\mathrm{P}<0.001$. Significant relative to Control.

\section{Discussion}

An immediate product of ethanol metabolism is acetaldehyde which is involved in a number of non- enzymatic modifications of proteins, including formation of semialdehydes, mercapto-semialdehydes and Schiff bases with consequent protein modification and inhibition of their biological functions (Morgan et al., 2002).

In the present study, alcohol administration leads to hyperglycemia in concomitant with decline in serum insulin level and decrease liver glycogen content Siler et al. (1998) found that, alcohol intake increased glycogenolysis accomp-anied by reduced gluconeogenesis.

These results may be attributed to decrease insulin level by chronic alcohol intake as reported by Lazarus et al. (1997).

Chronic ethanol consumption decreased the total glycogen synthesis activity which correlated closely with a loss in glycogen synthase protein (Van Horn et al., 2001) as well as depressed rate of synthesis or an increase rate of breakdown.

In addition, it is predictable that, prolonged exposure to ethanol would associated with the over production of reactive oxygen species (ROS) induce oxidative stress and inhence lysis of liver glycogen (Petersen et al., 2005).

As honey rich in $\mathrm{K}^{+}$content, obtained amelioration in alcohol treated group received honey, may be attributed to $\mathrm{K}^{+}$ content that exceed pancreatic insulin secretion where Hiatt et al. (1972) reported that, the increase of $\mathrm{K}^{+}$within the physiological range increases the secretion of pancreatic insulin.

The amelioration caused in case of urtica is in accordance with previous study of (Bnouham et al., 2003) who reported that, aquous extract of Urtica dioica had a significant antihyperglycemic effect; this result may be caused in part by the reduction of intestinal glucose absorption.

G-6-Pase may participate in the phosphorylation of glucose by using phosphate donor carbamoyl phosphate when the sugar concentration is elevated as in diabetes (Nordlie, 1964). Obtained hyper-glycemia indicate that G-6-Pase may have physiological role in glucose production (Bontemps et al., 1978).

The decreased G6PD activities in liver and pancreas during hyperglycemia can be explained by a reduced insulin secretion and action, or inhibition of this 
enzyme due to a phosphorylation or oxidative modification (Diaz-Flores, et al., 2006).

The increments in serum total lipid and cholesterol in the present data may be resulted from excessive lipolysis from fat depot due to catecholamine secretion and defective removal at lipid from blood by ethanol which mediated decreased lipoprotein lipase activity (Nakamura, 1994). Where, adrenergic hyperactivity is a common finding with chronic ethanol intake (Diamond, 1996), that is mainly ascribed to acetaldehyde, the interme-diated metabolite at ethanol that directly causes the release of catecholamines from the tissues (Sano et al., 1992).

Also, these results may be due to decrease the hepatic mitochondrial oxidation of fatty acids as a result of decrease NAD and high NADH, where Enomoto et al. (2002) reported that, the metabolism of ethanol into acetaldehyde by alcohol dehydrogenase and the metabolism of acetaldehyde into acetate by acetaldehyde dehydrogenase both transform NAD into NADH.

The hypercholestrolaemia obtained in this study reflect perturbation of lipid transport system by alcohol consumption affecting lipid metabolism in both hepatic and extra hepatic tissues as well as its marked toxic effect on liver function (Duhamel et al., 1984).

The obtained decline in $\mathrm{HDL}_{\mathrm{C}}$ level noted in alcohol treated group, may be due to reduced Apo B level as mentioned by Taskinen et al. (1987).

Schroder et al. (2006) Reported that, increased alcohol consumption was associated with an increment in ox-LDL plasma concentration.

The obtained elevation of triglyc-eride in alcohol treated group agrees with Little et al. (1986) who reported that alcohol can elevate triglycerides.

The protection of honey may be due to the release of protective agents and the involvement of $\mathrm{SH}$ group in the protective mechanism of honey (Ali, 1995).

The enhanced protection caused by urtica may be due to their polyphenol content as reported by McDonald et al.
(1998) who stated that polyphenols exert a large array of biological actions such as free radical scavenging, metal chelation and enzyme modulation which are responsible for the antioxidant activity

The noticed lower serum total protein in alcohol treated group may be explained by nutrition insufficiency or liver damage commonly occur from alcohol, where Diamond, (1996) showed that, alcohol supplies some calories needed by the abuser, depresses appetite, cause liver damage and in hence defective protein synthesis. Also, the toxic effect of ethanol on hepatocytes may depress protein synthesis by the liver (Preedy et al., 1994).

The present results showed high serum urea level in alcohol treated group. A result which may be due to direct damage to the kidney, (Heidland et al., 1985) or indirectly affect renal function by elevating blood pressure, (Marmat et al., 1994) inducing electrolyte imbalance (Vamvakas et al., 1998) and inducing hyperuricaemia, (Yamanaka, 1996).

Obtained increase in MDA and PC may be attributed to lipid peroxidation by alcohol where chronic ethanol consumption increased hepatic lipid peroxidation (Roig et al., 2000). These results perhaps due to the chronic oxidative stress in alcoholism that can lead to oxidative modification of protein (Patel et al., 2005), such modification occur principally by formation of protein carbonyl.

These results may be due to increase formation of ROS by $\mathrm{CYP}_{2} \mathrm{E}_{1}$ through ethanol consumption, where Letteron et al. (1996) reported that ethanol consum-ption increases the formation of ROS by $\mathrm{CYP}_{2} \mathrm{E}_{1}$ which triggers lipid peroxidation in mice.

In addition, the decline in antioxidant defense system may lead to these results as it was noted by Jurczuk et al. (2004) who stated that after ethanol ingestion the antioxidant defense system in the liver is insufficient to give complete protection and thus the process of lipid peroxidation escalated.

Excess iron release from haemol-yzed $\mathrm{RBC}_{\mathrm{S}}$ by alcohol may lead to these lipid peroxidation, where iron can stimulate lipid peroxidation by the fenton reaction, and 


\section{G.M.F Edrees et al}

also accelerates peroxidation by decomposing lipid hydroperoxides into peroxyl and alkoxyl radicals that can themselves abstract hydrogen and perpetuate the chain reaction of lipid peroxidation (Chang et al., 2002).

Amelioration caused by honey may be attributed to the involvement of $\mathrm{SH}$ in the protective mechanism of honey as shown by Szaba et al., (1981) and Ali (1995) who showed that SH may play a role in these ameliorative processes.

The obtained amelioration by urtica or honey administration is corroborated by reduced levels of MDA and protein carbonyl level in liver and pancreas of animals received alcohol with urtica or honey or both, these results may be attributed to elimination of ROS by SOD and CAT enzymes that protect lipid peroxidation (Jurczuk et al., 2004).

Glutathione has been recognized as a primary component in protecting hemoglobin, enzymes and red blood cell membranes from oxidative damage (Wintrobe et al., 1975).

The significant reduction of glutathione levels in the alcohol treated group may be explained through either increased peroxidation or increased loss from the liver, or impairment in its synthesis (Speisky et al., 1985).

The data presented in Table (3) reveal that alcohol intake greatly affect GST, GSH, CAT and SOD. These results coincide with, Ali et al. (1997) who reported that, ethanol decreased level of GSH. These results may be attributed to excess generation of ROS as a consequence of induction of cytochrome P-450 II E1 by ethanol consumption that plays a major role in ethanol-induced oxidative stress (Lecomte et al., 1994). Where, oxidative stress in the cells or tissues refers to enhanced generation of ROS and/or depletion in antioxidant defense system.

Honey is known to prevent ethanolinduced depletion of GSH (Ali, 1991). Hyperosmotic solutions of honey lead to an increase of prostacyclin formation in both antral and fundic mucosa of the rat.
The antioxidant capacity of Urtica may be attributed to the antioxidant actions of polyphenols (Rodrigo and Rivera, 2002).

Obtained decline in serum $\mathrm{Na} \& \mathrm{~K}$ concentrations of alcohol treated group is in accordance with Epstein, (1997) who stated that chronic alcohol consumption may experience low blood concentration of key electrolytes, impaired sodium, and fluid handling as well as it can disrupt hormonal control mechanisms that control kidney function. Also it may be due to increase sodium loss through excretion with urine as a result of exceed blood pressure as mentioned by Parekh et al. (2001).

Ethanol abuse induced magnesium deficiency; as shown in table (4) Magnesium is an obligatory factor in the enzyme reactions of GSH synthesis (Mills et al., 1986); this decline is corroborated by low GSH level in alcohol treated group. This mineral was also restored it normal level to some extent in honey or Urtica treated group.

The decreased in $\mathrm{Cu}$ concentration in animals receiving alcohol is in accordance with Brzoska et al. (2002). The protective effects of honey may indicate that it possess antioxidant properties (Ali et al., 1997).

In conclusion, chronic ethanol use moderately increases the susceptibility of body systems abnormalities where honey or Urtica may chair in the protection of these alterations.

\section{References}

1. Ali A (1991): Prevention of ethanol-induced gastric lesions in rats by natural honey, and its possible mechanism of action. Scand. J. Gastroenter. 26:281288.

2. Ali A (1995): Natural honey accelerates healing of indomethacin-indueed antral ulcers in rats. Saudi Med. J. 16:161-166.

3. Ali $M$ and A1-Swayeh OA (1997): Natural honey prevents ethanol-induced increased vascular permeability changes in the rat stomach. J. Ethnopharmacol., 55:231-238. 
4. Bnouham M, Merhfour F-Z, Ziyyat A, Mekhfi H, Aziz $M$ and Legssyer A (2003): Antihyperglycemic activity of the aqueous extract of Urtica dioica. Fitoterapia., 74:677-681.

5. Bontemps $\mathbf{F}$, Hue $L$ and Hers $H$ G (1978): Phosphorylation of glucose in isolated rat hepatocytes. Sigmoidal kin-etics explained by the activity of glucok-inase alone. Biochem. J., 174:603-611.

6. Brzoska MM, MoniuszkoJakoniuk J, Jurczuk $M$ and Galazyn- Sidorczuk M (2002): Cadmium turnover and changes of zinc and copper body status of rats conti-nuously exposed to cadmium and ethanol. Alcohol and Alcoholism., 37:213-221.

7. Chang LW, Yen WJ, Huang SC and Duh PD (2002): Antioxidant activity of sesame coat. Food Chem., 78:347-354.

8. Diamond I (1996): Alcoholism and alcohol abuse. In: Cecil Text book of Medicine $20^{\text {th }}$ ed. Edit: Bennet J.C. and plum F, Shounderes. Company, Philadilphia, London, Torento. Vol $\underline{1}$, P.47.

9. Diaz-Flores M, IbanezHernandez MA, Galvan RE, Gutierrez M, Duran-Reyes G, Medina-Navarro R, Pascoe-Lira D, Ortega-Camarillo C, VilarRojas C, Cruz $M$ and BaizaGutman LA (2006): Glucose-6phosphate dehydrogenase act-ivity and $\mathrm{NADPH} / \mathrm{NADP}^{+}$ratio in liver and pancreas are dependent on the severity of hyperglycemia in rat. Life Sci., 78: 2601-2607.

10. Duhamel G, Nalpas B, Goldstein S, Laplaud PM, Bertheolet P and Ohampan MJ (1984): Plasma lipoprotein and Apolipoprotein profile in alcoholic patients with and without liver disease: on the relative roles of alcohol and liver injury. Hepatol., 4: 577-85.

11. Enomoto N, Takei Y, Hirose M, Ikejima $K$, Miwa $H$ and Kitamura T (2002): Thalidomide prevents alcoholic liver injury in rats through suppression of Kupffer cell sensitization and
TNF-alpha production. Gastroenter. 123:291-300.

12. Epstein M (1997): Alcohol's Impact on Kidney Function. Alcohol Health \& Res. World., 21(1):84-93.

13. Heidland A, Horl WH, Schaefer RM, Teschner M, Weipert $J$ and Heidbreder E (1985): Role of alcohol in clinical neph-rology. Klin Wochenschr, 63: 948-958.

14. Hiatt N, Davidson $M B$ and Bonorris G (1972): The effect of potassium chloride infusion on insulin secretion in vivo. Hormone Metab.Res., 4:64:68.

15. Jurczuk M, Brzoska MM, Moniuszko-Jakoniuk J, Galazyn-Sidorczuk $M$ and Kulikowska-Karpinska E (2004): Antioxidant enzymes activity and lipid peroxidation in liver and kidney of rats exposed to cadmium and ethanol Food and Chem. Toxicol., 42:429-438.

16. Lazarus $R$, Sparrow $D$ and Weiss ST (1997): Alcohol intake and insulin levels: the Normative Aging Study. Am. J. Epidemiol., 145:909-16.

17. Lecomte $\mathbf{E} \mathbf{B}$, Herberth $\mathbf{P}$, Pirollet Y, Chancerelle J, Armando N, Musse F, Paille G, Siest $G$ and Artur $Y$ (1994): Effect of alcohol consumption on blood antioxidant nutrients and oxidative stress indicators. Am. J. Clin. Nutr., 60:255-261.

18. Letteron P, Fromenty B, Terris B, Degott $C$ and Pessayre D (1996): Acute and chronic hepatic steatosis lead to in vivo lipid peroxidation in mice. J. Hepatol., 24:200-208.

19. Little JA, Graves K, Suchindran CM, Milner J, McGuire V, Beaton F, Feather T, Mattson FH, Christiansen D and Williams OD (1986): Customary diet, anthropometry, and dyslipoprot-einemia in selected North American populations: the Lipid Research Clinics Program Prevalence Study. Circulation, 7380.

20. Marmot MG, Elliott $P$ and Shipley MJ (1994): Alcohol and 


\section{G.M.F Edrees et al}

blood pressure: the intersalt study. Br. Med. J., 308: 1263-1267.

21. McDonald MS, Hughes M, Bruns J, Lean MEJ, Matthews D and Crozier A (1998): Survey of the free and conjugate myrcetin and quercetin content of red wines of different geographical origins. J. Agric. and Food Chem. 46:368 375.

22. Meera V, Hemrajpal and Singh R (2001): Discriminative Value of Lipids and Apolipoproteins in Alcoholics. Prog. NeuroPsychophormacol.\&Biol. Psychiat. 25:1011-1022.

23. Mills BJ, Linderman RD and Long CA (1986): Magnesium deficiency inhibits biosynthesis of blood glutathione and turnover growth in the rat. Proc. Soc. Exp. Biol. Med., 18:326-331.

24. Morgan PE, Dean RT and Davies MJ (2002): Inactivation of cellular enzymes by carbonyls and protein-bound glycation/ glycoxidation products. Arch. Biochem. Biophys,. 403:259-269.

25. Nakamura J (1994): Effect of short-term and long-term alcoholic intake on plasma cholesterol in non alcoholic humans. Clinc. Chem. Acta., 24:107-109.

26. Nordlie $\mathbf{R} \mathbf{C}$ and Arion $\mathbf{W} \mathbf{J}$ (1964): Evidence for the common identity of gluc-ose 6-phosphatase, inorganic pyrophosp-hatase, and pyrophosphate-glucose phosphotransferase. J. Biol.Chem., 239: 1680 - 1685.

27. Parekh RS and Klag MJ (2001): Alcohol: role in the development of hype-rtension and end-stage renal disease. Curr. Opin. Nephrol. Hypertens. 10: 385-390.

28. Patel VD, Worrall SW, Emery PW and Preedy VR (2005): Protein adduct species in muscle and liver of rats following acute ethanol administration. Alcohol Alcohol, 40: 485-493.

29. Petersen DR (2005): Alcohol, iron-associated oxidative stress, and cancer. Alcohol, 35:243-249.

30. Preedy VR, Siddig T, why HJF and Richard PJ (1994): Ethanol toxicity and cardiac protein synthesis in vivo. Am. Heart. J. 127:1432-1439.

31. Rodrigo R and Rivera G (2002): Renal damage mediated by oxidative stress: a hypothesis of protective effects of red wine. Free Radical Biol. and Medic. 33: 409422.

32. Roig R, Cascon E, Arola L PhD, Blade C PhD and Salvado MJ PhD (2000): Effects of chronic wine and alcohol intake on glutathione and malondialdehyde lev-els in rats. Nutri. Res. 20(11):1547-1555.

33. Sano H, Suzuki Y and Ohara K (1992): Circadian variation in plasma homova-nillic acid level in alcoholic patients. Alcohol.Clin.Exp.Res.Dec.16(6):1 047-51.

34. Schroder H, Marrugat J, Fíto $M$, Weinbrenner $\mathbf{T}$ and Covas M-I (2006): Alcohol consumption is directly associ-ated with circulating oxidized low-density lipoprotein. Free Radical Biol. \& Medic. 40:1474-1481.

35. Siler SQ, Neese RA and Christiansen MP (1998): Hellerstein, M.K. The inhibition of gluconeogenesis following alcohol in humans, Am. J. Physiol. 275:E897- 907.

36. Speisky H, MacDonald A, Giles G, Orrego $H$ and Israel $Y$ (1985): Increased loss and decreased synthesis of hepatic glutathione after acute ethanol adminis-tration. Biochem. J. 225: 565-572

37. Szabo S, Trier JS and Frankel PW (1981): Sulfhydryl compounds may med-iate gastric cytoprotection. Sci.214: 200-2.

38. Taskinen MR, Nikklla EA, Valimaki M, Sane T, Kussi T, Kesaniemi $A$ and Ylikahri $R$ (1987): Alcohol induced changes in serum lipoproteins and their metabolism. Am. Heart J. 113: 458-464.

39. Vamvakas S, Teschner $\mathbf{M}$, Bahner $U$ and Heidland $A$ (1998): Alcohol abuse: potential role in electrolyte disturbances and kidney diseases. Clin. Nephrol. 49: 205-213. 
40. Van Horn CG, Ivester $\mathbf{P}$ and Cunningham1 CC (2001): Chronic ethanol consumption and liver glycogen Synthesis. Arc. Biochem. and Biophys. 392(1): 145-152.

41. White Jr (1979): Composition of honey. In: E. Came (Ed.), Honey: A Compreh-ensive Survey. Heinemann, London, pp. 157- 206.

42. Wintrobe WM, Lee RG, Boggs DR, Bithell TC and Forester J (1975): The erythrocyte, intrinsic metabolism function, laboratory evaluation. Chapter 3, Clinical Hematology, 7th edition,
Philadelphia, PA, Lea and Febiger, pp. 103-104.

43. Yamanaka H (1996): Alcohol ingestion and hyperuricemia. Nippon Rinsho. 54: 3369-3373.

44. Yesilada E, Honda G, Sezik E, Tabata M, Goto $\mathrm{K}$ and Ikeshiro Y (1993): Traditional medicine in Turkey IV. Folk medicine in the Mediterranean subdivi-sion. J. Ethnopharma. 39:31-38.

45. Yesilada E, Sezik E, Honda G, Takaishi Y, Takeda $Y$ and Tanaka T (2001): Traditional medicine in Turkey $X$. Folk medicine in Central Anatolia. J. Ethnop-harma. 75:95-115.

\section{التاثير الواقى لعسل النحل واليورتيكا والخليط منهما ضد الثد التاكسدى الناجم عن التناول

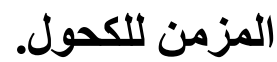

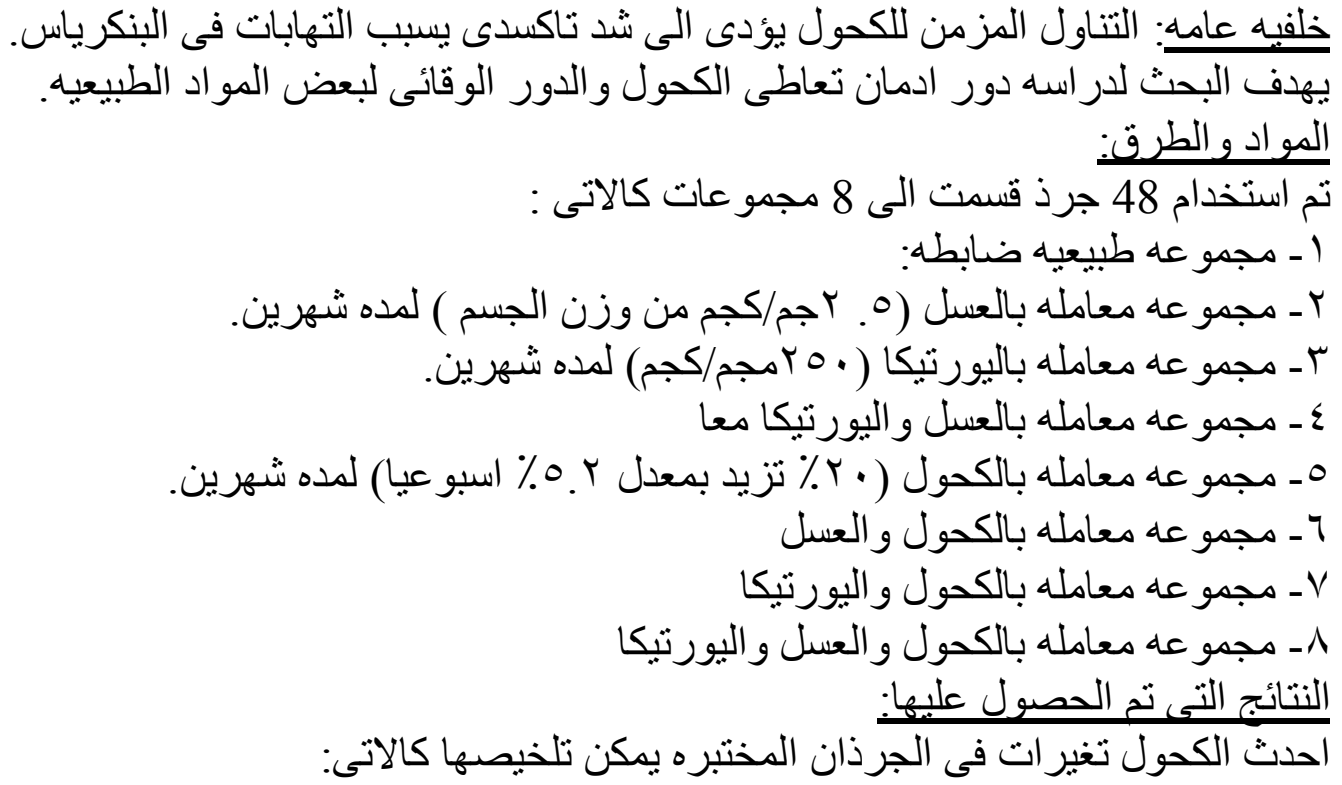




\section{G.M.F Edrees et al}

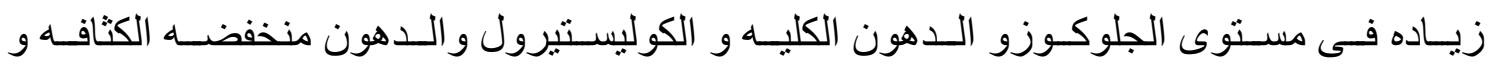

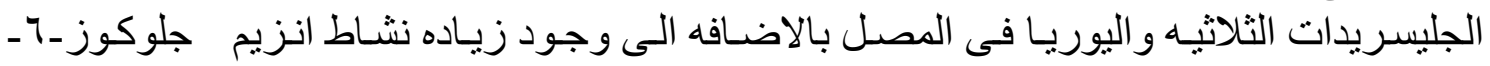
فوسفاتيز بالكبد و زياده دلالات الدهون فوق المؤكسده فى الكبد والبنكرياس.

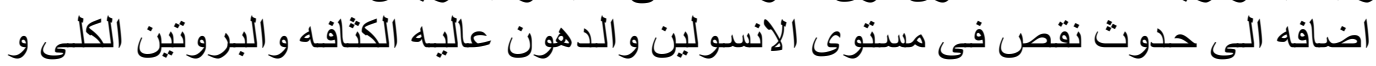

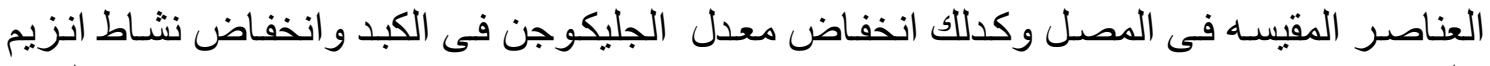

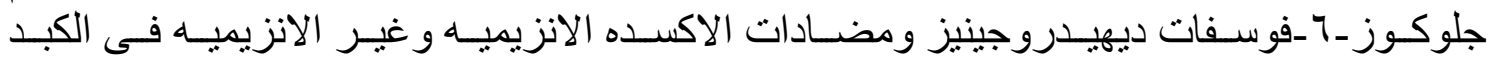
و البنكرياس.

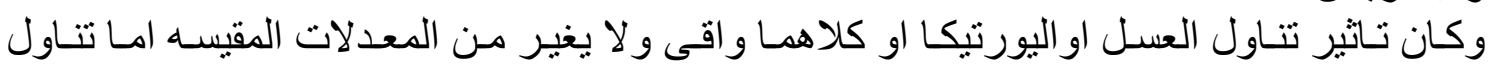

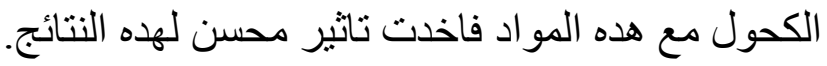

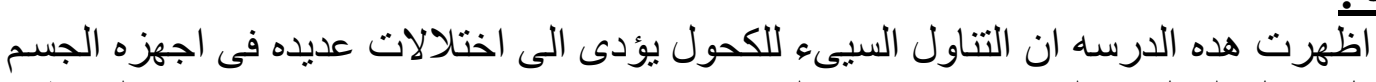

الخلاصه: - الخصع

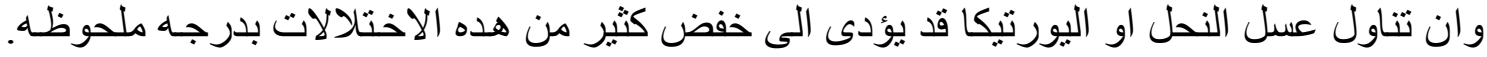

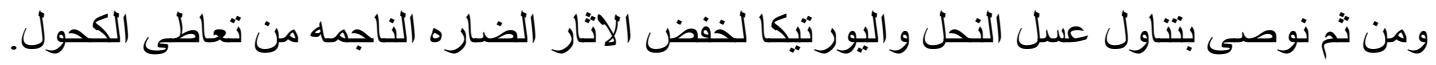

